\title{
Economic valuation of sportfishing in the surroundings of Cerralvo Island, Baja California Sur, Mexico using the travel cost method
}

\author{
Luis C. Almendarez-Hernández ${ }^{1}$, Marian Rodríguez-Fuentes ${ }^{1}$ \\ Francisco J. Vergara-Solana ${ }^{1} \&$ Marco A. Almendarez-Hernández ${ }^{2}$ \\ ${ }^{1}$ Instituto Politécnico Nacional, Centro Interdisciplinario de Ciencias Marinas \\ Departamento de Pesquerías y Biología Marina, Programa de Doctorado Interinstitucional \\ de Bioeconomía Pesquera y Acuícola, La Paz, Baja California Sur, México \\ ${ }^{2}$ Centro de Investigaciones Biológicas del Noroeste, Oficina de Propiedad Intelectual y Comercialización \\ de Tecnología, La Paz, Baja California Sur, México \\ Corresponding author: Marco A. Almendarez-Hernández (malmendarez@ cibnor.mx)
}

\begin{abstract}
Los Cabos, Baja California Sur, Mexico, is a reference for sportfishing (SF). In this vein, a significant number of artisanal fishers from the communities surrounding Cerralvo Island-located $215 \mathrm{~km}$ from Los Cabos-have opted to offer SF as a tourist service in recent years. The SF has generated unevaluated economic activity in the area. Thus, stakeholders need to know this value to improve their management decision making. Therefore, this research aimed to make a valuation of the recreation service and factors that influence the demand of SF in Cerralvo Island and surrounding areas using the indirect travel cost method (TCM). For this purpose, 275 surveys were performed at the boat ramps in nearby towns. The estimated consumer surplus (EC) was USD 1,886 per visitor. Approximately 28,864 annual recreational sportfishing trips were recorded, so the total annual surplus was USD 54,437,504. The EC outperformed other national sites and was $\approx 140 \%$ higher than the highest valuation made for Los Cabos, which presumably derived from the differences in costs (v. gr., fishing charter, lodging). These values suggest the opportunity for the development of this activity in the study area.
\end{abstract}

Keywords: economic valuation; recreational use-value; protected natural area; consumer surplus; sustainable tourism

\section{INTRODUCTION}

Deep-sea sportfishing is relevant worldwide as a recreational and leisure activity, generally considered sustainable and an engine that contributes to the development of the tourism sector (Ditton et al., 1996; Cisneros-Montemayor \& Sumaila, 2010). This activity concentrates a significant number of fishers related to the seasons of abundance and distribution of the target species (Ponce-Díaz et al., 2003; Ortega-García, 2010; Gómez-Cabrera \& Ivanova-Boncheva, 2013).

In a global context, places, where sportfishing is of great importance, are considered both from an economic and cultural perspective; for example, those that stand out are Cairns in Australia, Bay of Island in
New Zealand, Kailua-Kona in Hawaii and Cabo Blanco in Peru (Pérez-Valencia, 2004), as well as different sites on the coasts of Mexico (Gómez-Cabrera \& Ivanova-Boncheva, 2013).

The most iconic areas to practice sportfishing in Mexico are Acapulco and Ixtapa Zihuatanejo in the state of Guerrero; Puerto Vallarta in Jalisco; Manzanillo in Colima; Mazatlan in Sinaloa; and Los Cabos in Baja California Sur (BCS) (Hernández-Trejo et al., 2012). For the state of BCS, sportfishing is a significant economic activity because it generates a substantial amount of income in foreign currency (for service providers and businesses in the entity) and jobs (Gómez-Cabrera \& Ivanova-Boncheva, 2013). 
Baja California Sur has four main destinations for sport fishers: i) Los Cabos, ii) Los Barriles-Buenavista, iii) Loreto, and iv) La Paz (Barr \& Mourato, 2009; Gómez et al., 2011; Hernández-Trejo et al., 2012). However, in recent years a significant number of artisan fishers from the towns surrounding Cerralvo Island, have opted to offer tourism services focused on recreational sportfishing.

Cerralvo Island, privately owned, is located within the municipality of $\mathrm{La} \mathrm{Paz}$ and is part of the natural reserve "Islas del Golfo de California," which falls within the category of Protected Natural Area (PNA). Among the most prominent localities around Isla Cerralvo are La Ventana, El Sargento, Agua Amarga, and Ensenada de Muertos as the main point of concentration.

Currently, this area has sportfishing as one of the main tourist activities that take place during the summer months. Moreover, commercial fishing and tourism activities, such as kitesurfing, windsurfing, kayaking, spearfishing, boat rides, and camping, among others, are also taking place around Cerralvo Island (Galvan-Magaña et al., 1996; García et al., 2013).

The main target species for sportfishing in the area are pelagic species, of which billfish stand out: striped marlin (Tetrapturus audax), blue marlin (Makaira nigricrans), and black marlin (Makaira indica). Other species are also caught, such as mahi-mahi (Coryphaena hippurus), yellowfin tuna (Thunnus albacares), wahoo (Acanthocybium solandri), yellowtail (Seriola lalandi), amberjack (Seriola rivoleana), roosterfish (Nematistius pectoralis), sierra (Scomberomorus sierra), and bonito (Sarda chiliensis) (Klimley \& Butler, 1988; Galvan-Magaña et al., 1996; Del MoralFlores et al., 2013).

Besides, a wide variety of bottom fish are also targeted by sport fishers including several species of snappers (Lutjanus argentiventris, L. aratus, L. novemfasciatus, L. peru, Hoplopagrus guentherii); groupers (Mycteroperca rosacea, M. xenarcha, Paralabrax maculatofasciatus); and triggerfish (Balistes polylepis, Sufflamen verres) (Klimley \& Butler, 1988; GalvanMagaña et al., 1996; Del Moral-Flores et al., 2013).

To our knowledge, no studies estimating the economic value of the ecosystem services provided by this island are available in the context of sportfishing. Stakeholders need to know this value to improve the management decision making of this activity and promote sustainable public policies. Therefore, the purpose of this study was to economically value the recreational service, as well as determinants of the demand for sportfishing services (trolling lures and baitfish, bottom fishing and fly fishing) in Cerralvo
Island and surrounding areas using the travel cost method (TCM) (Prayaga et al., 2010; Gómez et al., 2011; Hernández-Trejo et al., 2012).

\section{MATERIALS AND METHODS}

\section{Study area}

Cerralvo Island is located at the entrance of the Gulf of California $\left(24^{\circ} 12^{\prime} \mathrm{N}, 109^{\circ} 48^{\prime} \mathrm{W}\right)$ (Fig. 1), and separated off the BCS coast by the Canal of Cerralvo, a channel that has an approximate extension of $13 \mathrm{~km}$. This island has a territorial extension of $29 \mathrm{~km}$ long and $7 \mathrm{~km}$ wide. Currently, Cerralvo Island is recognized as a World Heritage Site by UNESCO.

The total study area includes Cerralvo Island as the natural capital that provides environmental services, and the nearby towns of El Sargento, La Ventana, and Ensenada de Muertos as concentration sites for tourism service providers and visiting users.

\section{Data collection}

A field trip to the study site was made to know the influx of visitors since no official records existed of the trips made by sportfishing vessels to this site. In this manner, a representative sample could be estimated to identify the number of visitors per year. The fieldwork consisted of conducting semi-structured interviews with key informants: boat captain, owner of a tourism company, and member of a non-governmental organization (NGO) who worked on technical aspects of coastal fishing in the region for one year.

Based on these interviews, around 82 vessels operate in the region in sportfishing services. The activity has two seasons per year: high (HS) with a duration of 31 weeks and low (LS) with a span of 21 weeks. During the HS (April to November), the boats have five departures per week while they have one in LS (December to March). Finally, on average, the vessels carry two fishers on board, which led to establishing the universe of sportfishers in 28,864 visitors per year approximately.

From this, a parametric model was used to estimate the sample size based on population universe $(\mathrm{N})$ and the parameters: margin of error and confidence level, and finally, on the heterogeneity of the responses. The model to calculate the sample size is shown in the equation (1) (Levin \& Rubin, 2010):

$$
n=\frac{N * Z^{2} * p *(1-p)}{(N-1) * e^{2}+Z^{2} * p *(1-p)}
$$

where $n$ : sample size; $N=$ population universe $(28,864$ visitors per year); $Z=$ deviation from the accepted average value to achieve the desired level of confidence $(\alpha=0.05 ; Z=1.96) ; e=$ maximum admitted error 


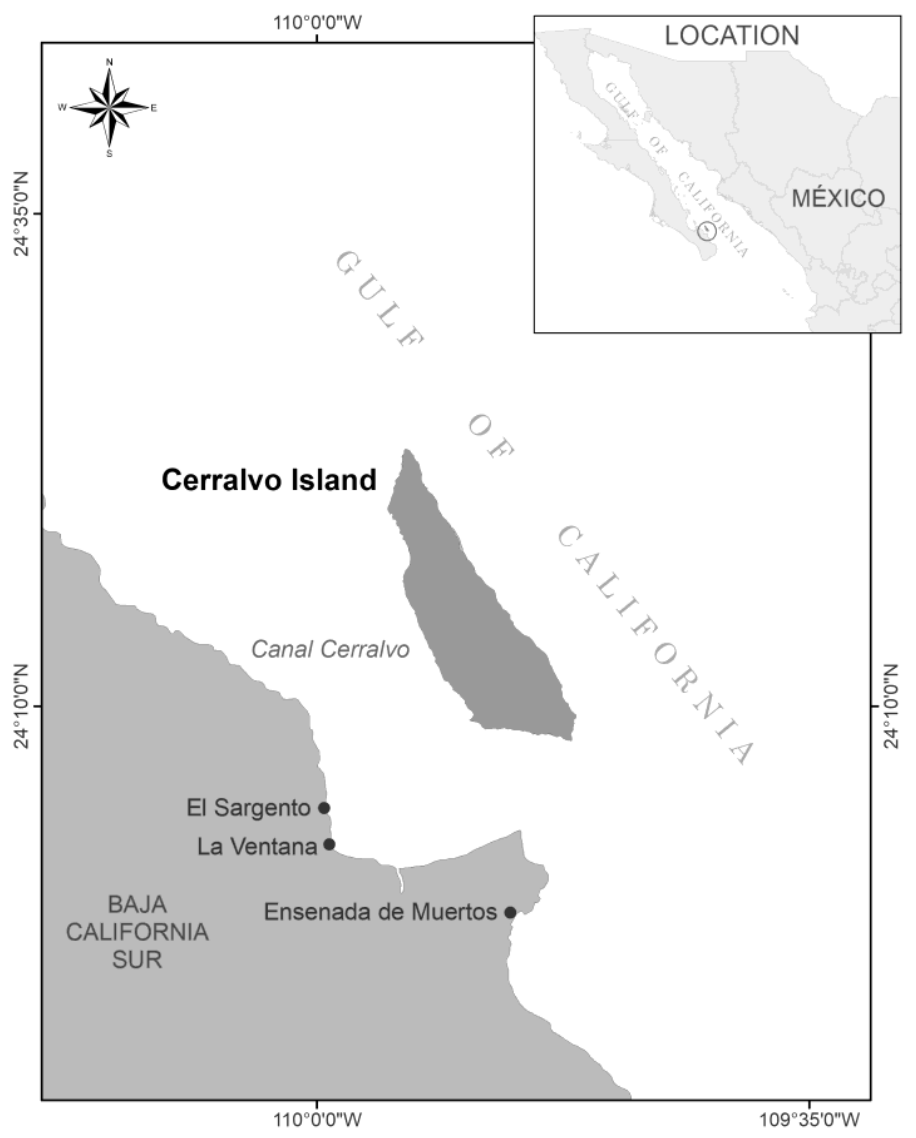

Figure 1. Map of Cerralvo Island showing the most influential localities in the area: El Sargento, La Ventana.

margin $(5 \%) ; p=$ represents the ratio of population individuals that have the characteristic of practicing sportfishing (in this case 0.5 , considering error in the worst scenario).

With these parameters, the estimated sample size was 380 surveys. Once the database was debugged, surveys with errors in the answers, outliers, and incomplete surveys were removed; a total of 275 valid survey questions were obtained, avoiding possible bias in estimations. Despite a lower level of confidence was considered ( $\alpha=0.10 ; Z=1.65)$, sampling size would be 267 surveys, with which good representativeness was achieved. The sample was used to describe the angler's profile (v. gr., origin, educational level, work status, target species, income), estimate the travel demand, and calculate the economic benefits perceived by the sport fishers visiting Cerralvo Island.

The information was collected using the technique of insitu surveys, conducted face-to-face, which included closed and open responses (Vuelta \& De la Fuente, 2004; Abascal \& Esteban, 2005). Visits were made on boat ramps of El Sargento, La Ventana, and
Ensenada de Muertos every 15 days from June 2016 to June 2017.

\section{Economic valuation by the travel cost method (TCM)}

The analysis is divided into two stages: 1) preparation of a demand function including all identified costs incurred to perform sportfishing in the area, and 2) construction and parameterization of the demand curve that best represented the relationship between the number of visits to the site and the factors that determined this number of visits. The data analysis and the parameterization of the TCM model were performed using the software NLogit 5.0.

The Poisson count model was used (Haab \& McConnell, 2002), specifying the number of trips demanded as a random number with a mean dependent of exogenous regressors. In this case, the dependent variable was the number of trips to Cerralvo Island to perform sportfishing activities.

The econometric model to estimate travel demand $X_{i j}$ of, the individual $i$ for the site $j$ (Cerralvo Island) 
with explicit arguments sticks to the general form of the equation (2) (McConnell \& Strand, 1981):

$$
x_{i j}=f\left(c_{i j}, y_{i j}, z_{i j}, e_{i j}\right)
$$

where $C_{i j}$ : the cost of the individual's trip to the site; $Y_{i j}$ represents annual income; $Z_{i j}$ : a vector of explanatory variables of socioeconomic type and other environmental variables linked to the site; and, $e_{i j}$ : the stochastic term. Table 1 shows the variables that were used in the construction of the econometric model.

However, the estimation of the economic value based on the function of demand (ii) is subjected to two types of restrictions: (1) budgetary and (2) time. The first is defined according to equation 3 (Haab \& McConnell, 2002),

$$
\sum_{j=1}^{n} x_{i j} c_{i j}+z_{i} \leq y_{i}
$$

where $x_{i j}$ represents the trips made by individual $i$ to site $j=1 \ldots n$; where $n$ is the number of sites, and for this investigation, it is 1 . The model also assumes that the individual $i$ acquires a basket of goods $Z_{i}$ related to site $j$ at a price normalized to one; also, the individual cannot spend more than his/her income allows $\left(y_{i}\right)$.

Time restriction is composed as follows:

$$
\sum_{j=1}^{n} x_{i j} t_{i j}+h_{i}=T_{i}
$$

where $h_{i}$ : the individual's working hours for the period; $t_{i j}$ : the total time per trip; and $T_{i}$ : available time. Also, the model assumes that the $t_{i j}$ it is the same for all people.

The disbursed income is composed of $y_{i}=y_{i}^{0}+$ $w_{i} h_{i}$ where $w_{i}$ is the available income per unit of time, and $y_{i}^{0}$ represents the fixed income.

The individual preference function $i$ is defined by profit $u\left(x_{i 1}, \ldots x_{i n}, q_{1}, \ldots q_{n}, z_{i}\right)$, where $q_{j}$ is the exogenous quality for the site $j$; $y_{i}^{f}$ means that the disbursed income is a function of the available salary and fixed income. The quality and number of trips to the recreational sites provide profit, and travel time does not generate profit or disutility, it is neutral. The model supposes a weak complementarity between individual $x^{\prime} s$ and $q^{\prime}$.

If the model supposes that the number of recreational sites is two, the basic model for one site is expressed as follows:

$$
x_{i 1}=f_{1}\left(c_{i 1}+w_{i} t_{1}, \ldots c_{i n}+w_{i} t_{i n}, q_{1} \ldots q_{n}, y_{i}^{f}\right)
$$

The specification of a demand equation with a corner solution for site 1 of the individual $i$ is denoted as follows:

$$
x_{i 1}=f_{1}\left(c_{i 1}, c_{i 2}, t_{i 1}, t_{i 2}, q, y_{i}^{f}\right)
$$

With the corner solution, the time dedicated to recreation is not expendable with the time used for work, and it is not possible to transform it into the monetary cost.

The way of performing it with an interior solution in the labor market is based on the following equation:

$$
x_{i 1}=f_{1}\left(c_{i 1}+t_{i 1} w_{i}, \ldots c_{i n}+t_{i n} w_{i}, q_{1} \ldots q_{n}, y_{i}^{f}\right)(7)
$$

Consequently, the general formulation for the site demand is expressed as follows:

$$
\begin{gathered}
x_{i 1}=f_{1}\left(c_{i 1}+\delta_{i} t_{i 1} w_{i}, \ldots c_{21}+\delta_{i} t_{i 2} w_{i},\right. \\
\left.\left(1-\delta_{i}\right) t_{i 1}\left(1-\delta_{i}\right) t_{i 2,} \ldots q, y_{i}^{f}\right)
\end{gathered}
$$

where $\delta_{1}$ is equal to 0 for individuals with a corner solution in the labor market and 1 for the interior solution.

In this study, the objective of the general model of counting data was to estimate the frequency behavior of days per visit of the individuals to Cerralvo Island to enjoy the recreational ecosystem service of sportfishing. This approximation has been used to estimate the surplus of the average consumer of the PenedaGeres National Park in Portugal (Mendes \& Proença, 2011). The expression is represented as follows: $\operatorname{Pr}\left(x_{i}=n\right)=f\left(n, z_{i} \beta\right), n=0,1,2$. The dependent variable of the amount $x$ demanded may take values from 0 to greater numbers.

The Poisson probability mass function is expressed as:

$$
\operatorname{Pr}\left(x_{i}=n\right)=\frac{e^{-\lambda_{i} \lambda_{i}^{n}}}{n !}, n=0,1,2 \ldots
$$

where $\lambda_{i}$ is the average and the distribution variance, and it is required that $\lambda_{i}>0$ be specified as an exponential function $\lambda_{i}=\exp \left(z_{i} \beta\right)$, where $z_{i}$ is the vector of explanatory variables, as described in Table 1.

Travel cost is the cost of each recreation per trip. For this reason, the following consideration was taken: travel cost $=$ transportation to the site + lodging + meals + other expenses incurred during the trip (RiveraCastañeda, 2002); these data were obtained from each visitor when the surveys were applied.

This model has five assumptions (Haab \& McConnell, 2002; Hernández-Trejo et al., 2012): i) travel and time are proxy variables at the price of a recreational trip, ii) travel time is neutral; that is, it does not provide usefulness or disutility, iii) decision unit is trips of equal distance to the site of interest for each income, iv) trips are of simple purpose and v) the amount consumed is trips to the same location for all consumers.

Regarding the limitations of the model about the opportunity cost (McConnell \& Strand, 1981), it should be noted that it assumes that people perceive and respond 
Table 1. Variables included in the travel cost model.

\begin{tabular}{|c|c|}
\hline Variable & Definition \\
\hline Total cost per trip & The total cost of the trip to visit the recreational site (Cerralvo Island). \\
\hline Gender & Female or male. \\
\hline Age & Angler's age: less than or equal to 20 / 21-30 / 31-40 / 41-50 / 51-60 / 61-70 / more than 70 years. \\
\hline Reason for the trip & The main reason for the visit: fishing / no fishing. \\
\hline Importance of the activity & $\begin{array}{l}\text { Importance of the fishing activity in the decision to visit the recreational site: unimportant / important / } \\
\text { very important. }\end{array}$ \\
\hline Fishing days & $\begin{array}{l}\text { Dependent variable. Days that the fisher stays on the site, considering that each day a fishing trip was } \\
\text { made. }\end{array}$ \\
\hline Substitute sites & Sites where the user can do sport fishing with the same budget as this trip. \\
\hline Level of expertise & Level of fishing skills: amateur/intermediate/ expert. \\
\hline
\end{tabular}

to changes in the cost of travel in the same way as they would respond to changes in fees to enter the recreational area (e.g., Sutton et al., 2001). Besides, it is problematic to define and measure the opportunity cost of time or value of the time spent during the trip (McConnell \& Strand, 1981; Mankiw \& Taylor, 2017). If people enjoy the time they spend traveling, time is a benefit and not a cost, so the results are overestimated. Finally, the availability of substitute sites for a given user (alternative fishing sites) will affect the perceived value.

\section{Consumer surplus}

Consumer surplus (CS) was estimated by obtaining the data of visits per year as a dependent variable and travel cost as an independent variable (Costanza et al., 1997; Mankiw \& Taylor, 2017). The relationship between frequency of visits and cost of travel is negative, as is the case with the demand function of other goods or services, which indicates that consumer surplus decreases as travel cost increases (Hicks, 1943).

The CS per trip was estimated dividing 1 between the coefficient of the trip cost (TC) variable obtained by the TCM model (McKean et al., 2001):

$$
C S=\frac{1}{T C}
$$

Based on the study of Lansdell \& Gangadharan (2003), a confidence interval for a level of $95 \%$ confidence can be formulated as follows:

$$
C S_{L}=-\frac{1}{[T C+1.96(s e T C)]} ; C S_{U}=-\frac{1}{[T C-1.96(s e T C)]}
$$

where $C S_{L}$ is the lowest limit of the interval; $C S_{U}$ is the highest limit of the interval; seTC is the standard error of TC. Once the average estimate of the individual consumer surplus was calculated, it was multiplied by the number of total visits to the island for one year; thus, the surplus of the total consumer was estimated, representing the total economic value that visitors assign to sportfishing in Cerralvo Island.

\section{RESULTS}

\section{Sport fisherman profile}

According to the results, $66 \%$ of the total number of visitors surveyed was foreigners, mostly from the USA (61\%) (California, Washington, Arizona, Colorado, and Kansas) and from Canada and Brazil (5\%). The rest were Mexicans (34\%), mainly from Baja California Sur.

Figure 2 shows the age ranges of the sample. On the average, the most frequent tourists entered the age category from 31 to 40 (24\%) and 61 to $70(21 \%)$, then category 51 to $60(19 \%)$ and 41 to $50(17 \%)$. The lowest age categories were 21-30 (9\%), those over $70(7 \%)$, and those under 20 (3\%). As observed, most of the sport fishers surveyed were male (91\%).

The level of education tended to be high among visitors (Fig. 3); $50.2 \%$ had a college degree, and $25 \%$ had a graduate degree (Master's) or a higher level (e.g., Ph.D.).

According to the answers, anglers' work status was divided into four groups: (i) employed (77\%), referring to visitors linked to work; (ii) retired (18\%), no longer bound to work but received some type of income; (iii) students (4\%); and (iv) unemployed (1\%), with no income.

About visitor fishing preferences in Cerralvo Island area, the primary motivation for visiting the site; $74 \%$ of the respondents came mainly for sportfishing. The rest of the answers were oriented to family vacations $(12 \%)$, knowing the place $(4 \%)$, visiting a relative or friend $(2 \%)$, traveling with a friend $(2 \%)$ and other reasons $(4 \%)$, which included diving, business, and good weather.

About the species of most significant interest for the visitors surveyed, $25 \%$ preferred mahi-mahi as the first option of capture; 25\% marlin (Tetrapturus audax, Makaira nigricrans, M. indica); $21 \%$ wahoo (Acantho- 


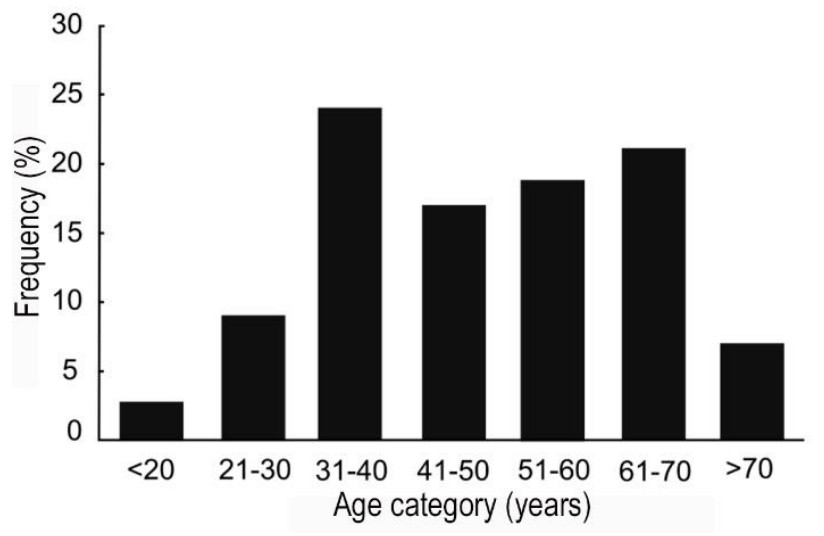

Figure 2. Age range (years) of the visitors surveyed.

cybium solandri); $18 \%$ yellowfin tuna (Thunnus albacares); and 9\% yellowtail (Seriola lalandi).

According to their criteria, the level of expertise was intermediate in $52 \%$ of the visitors; then, amateur $29 \%$, and finally, $19 \%$ classified themselves as angler experts. To corroborate the level of skills and experience in fishing, they were asked if they owned fishing equipment, to which $73 \%$ of the total responded having the necessary equipment to perform the activity. The annual income of the visitors surveyed during the study averaged USD 77,251 (USD 112,645 for foreigners and Mexicans USD 31,238).

\section{Econometric model}

From the econometric model, the following fishing trip coefficients were obtained for the surveyed visitors (Table 2). The descriptive statistics of the variables used in the regression model are shown in Table 3.

In general, Table 2 shows the coefficients associated with the seven independent variables. The significant variables to the model were: cost per day; male-gender; age from 21 to 30 and from 61 to 70; fishing as trip motivation, very important activity; the expert level of skills in fishing; and fishing days.

It was necessary to verify the assumption $E\left(x_{i} \mid z_{i} \beta\right)=\operatorname{Var}\left(x_{i} \mid z_{i} \beta\right)=\lambda_{i}$. This equality is known as equidispersion that implies the difficulty of getting a good fit to make valid inferences about the Poisson model parameters. The null hypothesis of equidispersion was not rejected because of the estimated critical chi-square value of 2.63 , which is relative to the critical chi-square for one degree of freedom of 3.84 with a level of significance of 0.05 .

The demand function for the economic valuation of Cerralvo Island sportfishing after parameterization was as follows:

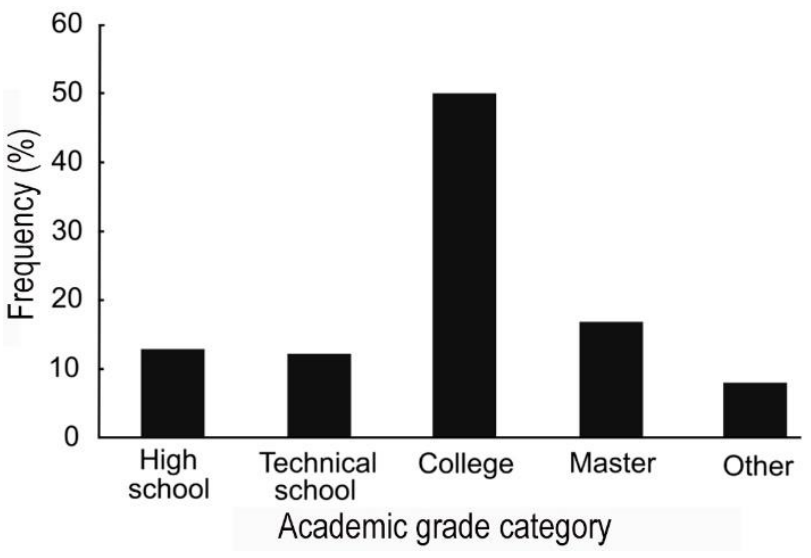

Figure 3. Level of education of the respondents.

Trips $=f($ total cost, gender, age, reason for the trip, substitute site, very important activity, expert skill level).

The coefficient of the variable cost per day showed a negative relationship. This parameter indicates that if the cost per day increases USD 1.00, the effect on the demand will be detrimental in a magnitude of $0.05 \%$. The male gender variable showed a positive sign, which suggested that men dedicated more time to sportfishing than women.

The variable age, in groups 21-30 and 61-70, showed a positive sign. The age groups are dummy variables. The age of contrast reference was the group of individuals aged younger than or equal to 20 , which can explain that the visitors of these two age groups tend to stay more days on the site, influencing the demand by 126 and $98 \%$, respectively.

The variable dummy trip motivation also showed a positive coefficient, which suggested that visitors whose primary motivation for travel was sportfishing; it influenced demand by $19.8 \%$. Likewise, those for whom this activity was significant in their decision to travel, the variable had a positive coefficient, influencing demand by $18.7 \%$ more concerning the individuals for whom the activity was not important.

The level of expertise in fishing also had a positive relationship with the response variable. The coefficient result reflected that the condition of the visitors' experience level (expert), affected the permanence in the site in a positive way in $55.5 \%$ more concerning amateurs.

\section{Economic benefits}

Identifying the demand relationships allows estimating the surplus consumer average (CS), using the travel cost coefficient of the general model $=0.00053$ (Table 2). In this manner, the values in equation (3) were replaced, 
Table 2. Coefficients estimated by the travel cost method (TCM) model $(\mathrm{n}=275), \alpha=1 \% * * *, 5 \% * *, 10 \% *$.

\begin{tabular}{|c|c|c|}
\hline Variable & Coefficient & $\begin{array}{c}\text { Probability } \\
\text { of } z\end{array}$ \\
\hline Constant & -0.01010 & 0.9867 \\
\hline Daily cost & $-0.00053 * * *$ & 0.0000 \\
\hline Gender Male & $0.27178 *$ & 0.0834 \\
\hline Age $21-30$ & $1.26130 * *$ & 0.0315 \\
\hline Age $31-40$ & 0.93518 & 0.1089 \\
\hline Age $41-50$ & 0.78017 & 0.1833 \\
\hline Age $51-60$ & 0.58335 & 0.3215 \\
\hline Age $61-70$ & $0.97635^{*}$ & 0.0947 \\
\hline Age $>70$ & 0.34156 & 0.5743 \\
\hline Travel motivation & $0.19832 *$ & 0.0590 \\
\hline Substitute site & -0.10250 & 0.1596 \\
\hline Very important activity & $0.18799 *$ & 0.0011 \\
\hline Expert level & $0.55569 * * *$ & 0.0658 \\
\hline Fishing days & $0.07473 * * *$ & 0.0000 \\
\hline \multicolumn{3}{|l|}{ Poisson regression } \\
\hline Dependent variable & Fishing days & \\
\hline Significance level & $P<0.001$ & \\
\hline Log-Likelihood & -667.606 & \\
\hline AIC & 1363.2 & \\
\hline $\mathrm{Chi}^{2}$ (13 d.f.) & 264.7 & \\
\hline Pseudo $\mathrm{R}^{2}$ & 0.165 & \\
\hline
\end{tabular}

resulting in a CS of USD 1,886. According to the formula (11), the CS obtained ranged from USD 1,587 to USD 2,325 for a confidence interval of $95 \%$.

Based on the population universe of anglers visiting Cerralvo Island in one year (28,864 visitors), the total annual surplus of the consumer, according to the model proposed by this study was USD 54,437,504, with a confidence interval for a confidence level of $95 \%$ fluctuating from USD 45,817,357 to USD 67,122,397.

\section{DISCUSSION}

The profile description of the sport fisher who visits Cerralvo Island agrees with that described in Buenavista, BCS with specific characteristics, such as people over 50 years of age with a deep-rooted fondness for sportfishing and mostly residents of California (USA) who repeat their visit to perform this activity at least once a year (Ditton et al., 1996). However, it differs in terms of the visitor's productive status since, in this case, $77 \%$ of the respondents were occupationally active.

Likewise, the profile of the sport fisher who visits Cerralvo Island was different from that of Los Cabos (Hernández-Trejo et al., 2012). It was mentioned that visitors to Los Cabos have an average age of 34 with more diverse nationalities and characteristics that correspond to a type of "sun and beach" tourism that visit the area to enjoy the various tourist attractions offered by the place, not only the practice of sportfishing (Hernández-Trejo et al., 2012).

While, in Cerralvo Island, the majority of visitors are over 40 years of age and come specifically for sportfishing, which is consistent with the fact that the interviewees self-categorized most of the fishing levels from intermediate to expert. It is essential to take into account these preferences and characteristics of users for the proper promotion of this recreational activity, as shown by Von Borstel-Juárez et al. (2019). They classified two types of sport fishers, occasional and exclusive; the first one makes reference to those from 21 to 40 years of age with experience of beginners and as tourists; the second one refers to visitors from 41 to 71 years of age with a level of experience from intermediate to expert and with the only objective of practicing sports fishing.

This study obtained a high percentage of national tourism participation in recreational fishing activities, which differs from previous studies where low percentages of national tourism were found (Ditton et al., 1996; Chavez-Comparan \& Fischer, 2001; Hernández-Trejo et al., 2012). This result was supported by the fees of local service providers surrounding Cerralvo Island (Oliveto-Andrade, 2018; Von Borstel-Juárez et al., 2019) since local service fees (from 100 to USD 200) compared with those of the Los Cabos area (approximately USD 780), are not so expensive (Hernández-Trejo et al., 2012). Additionally, the difference in infrastructure and services that the visitor has access to in Los Cabos (international tourism destination) and Cerralvo Island (OlivetoAndrade, 2018; Von Borstel-Juárez et al., 2019) are different, as well as the proximity of this last site to the capital city of the State of Baja California Sur.

Regarding the level of education, the majority of the visitors surveyed had a level equivalent to or higher than university studies, which was consistent with the fact that people with a high level of education tend to appreciate outdoor recreational activities related to nature to a greater extent (Gligo, 1991). As to the income variable, the number of trips to this site was not significant to measure it, which suggested that income did not have a relevant effect on the number of fishing trips. It agrees with other studies on travel cost demand in the site for other recreational activities (Curtis, 2002; Laplante et al., 2006; Hynes et al., 2015, 2017).

The fact that age is an important determinant of the demand for outdoor recreation is congruent (RiveraCastañeda, 2002). Currently, new trends in tourism indicate high participation of older people, which coincides with the result obtained in this study, where $47 \%$ of the anglers surveyed were over 50 years old. 
Table 3. Descriptive statistics of the variables used in the regression model. SD: standard deviation.

\begin{tabular}{lcccc}
\hline Variable & Mean & SD & Min. & Max. \\
\hline Travel cost & 1186.37 & 1225.97 & 153.8 & 4666 \\
Gender male & 0.9083 & 0.2890 & 0 & 1 \\
Age 21-30 years & 0.0996 & 0.3000 & 0 & 1 \\
Age 31-40 years & 0.2351 & 0.4249 & 0 & 1 \\
Age 41-50 years & 0.1793 & 0.3844 & 0 & 1 \\
Age 51-60 years & 0.1952 & 0.3972 & 0 & 1 \\
Age 61-70 years & 0.2112 & 0.4089 & 0 & 1 \\
Age $>$ 70 years & 0.0677 & 0.2518 & 0 & 1 \\
Travel motivation & 0.7371 & 0.4411 & 0 & 1 \\
Substitute site & 0.5737 & 0.4955 & 0 & 1 \\
Very important activity & 0.0478 & 0.2138 & 0 & 1 \\
Expert level & 0.3267 & 0.4699 & 0 & 1 \\
Fishing days & 2.47 & 2.04 & 1 & 12 \\
\hline
\end{tabular}

In general, foreign visitors were identified to have higher annual revenues than national visitors, which agrees with the high income reported by the foreign tourism surveyed in Los Cabos and Buenavista (Ditton et al., 1996; Hernández-Trejo et al., 2012; GómezCabrera \& Ivanova-Boncheva, 2013). On the other hand, the application of differentiated quotas by tourism type (national and foreign) has been analyzed, for example, in the price of sportfishing permits (Hernández-Trejo et al., 2017). Faced with this measure, it explains the importance of taking into account the general context of environmental policy in tourism development and promotion.

Based on the results of the demand models, necessary information can be obtained for the authorities in charge of the administration of this activity. In this sense, knowing how significant variables affect travel demand can be a useful tool to encourage or discourage visits to Cerralvo Island according to the management objectives of the area (Davis \& Tisdell, 1996; Sutton et al., 2001). Mexican fishing statistics reported just over 10 million pesos collected from the sale of 50,928 sportfishing permits, only for the state of $\mathrm{BCS}$ and placing this entity as the most important in the country in this activity (CONAPESCA, 2014).

The estimation of consumer surplus for Cerralvo Island was higher concerning all the assessments made with TCM for sportfishing in northwestern Mexico (Ditton et al., 1996; Chavez-Comparan \& Fischer, 2001; Hernández-Trejo et al., 2012; Gómez-Cabrera \& Ivanova-Boncheva, 2013; Meza-Cuellar, 2017). Regarding CS, the previous values recorded a range from USD 391 in the case of Manzanillo to USD 782 for Los Cabos (Chavez-Comparan \& Fischer, 2001; Hernández-Trejo et al., 2012). The value of the annual surplus was within the range of published values, ranging from 3.06 MDD for Los Barriles and Buena
Vista to 72 MDD for the Los Cabos region (GómezCabrera \& Ivanova-Boncheva, 2013; Meza-Cuellar, 2017).

The difference of the CS, concerning the other sites of northwestern Mexico, is not likely due to a premium on the price generated by the opportunity to fish on Cerralvo Island since the other sites assessed in Baja California Sur were similar and close to each other. One explanation could be based on the differences in the cost structure of the trip since not only are fishing charters more economical in Cerralvo Island compared to Los Cabos and Los Barriles areas, but also the rest of the services are lower (i.e., lodging, transportation, food). In this sense, the differences in the CS would reflect an opportunity to improve service quality, so that these communities can better capitalize on their natural ecosystem services.

Regardless of the comparison of the CS among the Mexican tourist destinations, studies have highlighted that values are superior concerning other parts of the world; in Brazil, the angler's CS has been calculated from USD 86.35 to USD 138.91 (Shrestha et al., 2002). From a CS analysis of 10 countries, the values tended to go from USD 34.45 to USD 69.97 (Shrestha \& Loomis, 2001). These differences could be explained by the quality of sportfishing and the associated tourism services in Baja California Sur (Ortega-García et al., 2003; Gómez-Cabrera \& Ivanova-Boncheva, 2013).

As part of comparing the results about the annual surplus, it is essential to take into account that the differences may be due to the number of visits estimated to the area of interest. Furthermore, it is important to consider inflation differences of each year and country, as well as those in the purchasing power of each currency. Moreover, another point that should be taken into account is that economic valuation is static and represents the situation of the site in the time 
frame when it was made, in addition to the fact that it is not possible to extrapolate it (Hernández-Trejo et al., 2012).

It is important to mention that the TCM does not incorporate the benefits that the local population obtains or could obtain by the use of ecosystemic services because it captures values of recreational use exclusively associated with enjoying its biodiversity (Randall, 1994). Thus, the CS was higher in the study site in comparison with the rest of the BCS localities; nonetheless, to quantify if this difference can be translated into a margin for the development of services associated with sport fishing, it would be necessary to provide supplementary information with other methodologies. Examples of these methodologies are: i) contingent valuation to define an optimum price (Mitchell \& Carson, 2013), ii) multi-criteria analysis for decision-making that allows quantifying the relative importance of price and other variables of interest (e.g., vessel size, fishing time) in the decision to acquire the recreational service (Roehl et al., 1993; Hein et al., 2006); as well as iii) studies of the value chain and social welfare to know the distribution pattern of the benefits (Dekker, 2003).

Therefore, one must be prudent when interpreting the results and aware of the scope of the method used. Nevertheless, this work lays the foundations to have reference information for the implementation of management strategies for the area. As mentioned before, sportfishing services are a relatively recent activity in Cerralvo Island and its surroundings, so it is necessary to encourage the growth of activity in the area without losing the objective of sustainability.

\section{CONCLUSIONS}

The estimation of the econometric model determined that cost per day and fishing days were two relevant factors in trip demand for sportfishing in this area. However, the factors of very important activity (sportfishing), age from 21 to 30, fishing as a reason for the trip, level of expertise, gender (male) and age from 61 to 70 of visitors described and identified those that characterized to no small extent the sportfishers who visit Cerralvo Island.

In terms of cost per trip, the net benefit received by users of sportfishing in economic terms was estimated at USD 1,886 per visitor, above the estimated consumer surplus in other sites in northwestern Mexico. This situation provides an incentive to improve the quality of the services offered and make the appropriate use of the ecosystem services in the area.
Finally, the economic value obtained from sportfishing generated an annual surplus of approximately USD 54,437,504. This estimation was based on the number of visitors attending the area, and therefore, may vary compared to other recreational sites. Nonetheless, it represents a relevant estimate because the site is little known in terms of recreation activities.

\section{ACKNOWLEDGMENTS}

The authors thank the SEMARNAT-CONACYT fund for the support provided for the development of this research. Mainly the project "Economic valuation of the ecosystem services of the Gulf of California Islands: Case Study Isla Cerralvo and surrounding communities dedicated to recreational sportfishing (263218)", as well as IPN EDI program for the stimuli granted to the primary author; to D. Fischer for editorial services in English.

\section{REFERENCES}

Abascal, E. \& Esteban, I.G. 2005. Análisis de encuestas. ESIC Editorial, Madrid.

Barr, R.F. \& Mourato, S. 2009. Investigating the potential for marine resource protection through environmental service markets: an exploratory study from La Paz, Mexico. Ocean \& Coastal Management, 52: 568-577. doi: 10.1016/j.ocecoaman.2009.08.010

Chavez-Comparan, J.C. \& Fischer, D.W. 2001. Economic valuation of the benefits of recreational fisheries in Manzanillo, Colima, Mexico. Tourism Economics, 7: 331-345. doi: 10.5367/000000001101297900

Cisneros-Montemayor, A.M. \& Sumaila, U.R. 2010. A global estimate of benefits from ecosystem-based marine recreation: potential impacts and implications for management. Journal of Bioeconomics, 12: 245268. doi: 10.1007/s10818-010-9092-7

Comisión Nacional de Acuacultura y Pesca (CONAPESCA). 2014. Anuario estadístico de acuacultura y pesca 2014. Comisión Nacional de Acuacultura y Pesca, Mazatlán, 301 pp.

Costanza, R., d'Arge, R., De Groot, R., Farber, S., Grasso, M., Hannon, B., Limburg, K., Naeem, S., O'Neill, R.V. \& Paruelo, J. 1997. The value of the world's ecosystem services and natural capital. Nature, 387: 253-260.

Curtis, J.A. 2002. Estimating the demand for salmon angling in Ireland. Economic and Social Review, 33(3): 319-332.

Davis, D. \& Tisdell, C. 1996. Economic management of recreational scuba diving and the environment. Journal of Environmental Management, 48: 229-248. doi: 10.1006/jema.1996.0075 
Dekker, H.C. 2003. Value chain analysis in interfirm relationships: a field study. Management Accounting Research, 14: 1-23. doi: 10.1016/s1044-5005(02)000 67-7

Del Moral-Flores, L.F., González-Acosta, A.F., EspinosaPérez, H., Ruiz-Campos, G. \& Castro-Aguirre, J.L. 2013. Lista anotada de la ictiofauna de las islas del golfo de California, con comentarios sobre sus afinidades zoogeográficas. Revista Mexicana de Biodiversidad, 84: 184-214.

Ditton, R.B., Grimes, S.R. \& Finkelstein, L.D. 1996. A social and economic study of the recreational billfish fishery in the southern Baja area of Mexico. Texas A \& M University, Texas.

Galvan-Magaña, F., Abitia-Cardenas, L.A., RodríguezRomero, J., Pérez-España, H. \& Chávez-Ramos, H. 1996. Lista sistemática de los peces de la Isla Cerralvo, Baja California Sur, México. Ciencias Marinas, 22: 295-311.

García, J.U., Mancilla, J.J., Chávez, P.R.C. \& Martínez, C.L. 2013. Un análisis económico del turismo y sus impactos en los servicios de los ecosistemas costeros en Baja California Sur. México. Global Conference on Business and Finance Proceedings, 13(2): 696 pp.

Gligo, N. 1991. Las cuentas del patrimonio natural como instrumento de un desarrollo ambientalmente sustentable en América Latina y el Caribe. Naciones Unidas, CEPAL, LC/G 1652 P: 11-23.

Gómez-Cabrera, I.D. \& Ivanova-Boncheva, A. 2013. Valor económico de la pesca deportiva como fuente principal de atracción turística en los cabos, Baja California Sur, México. TURyDES, 6(15): 1-25.

Gómez, I., Ivanova, A., Ponce, G. \& Ángeles, M. 2011. Economic valuation of sport fisheries in Los Cabos, Baja California Sur, Mexico. WIT Transactions on Ecology and the Environment, 150: 517-524.

Haab, T.C. \& McConnell, K.E. 2002. Valuing environmental and natural resources: the econometrics of nonmarket valuation. Edward Elgar Publishing, Cheltenham.

Hein, T., Blaschke, A.P., Haidvogl, G., Hohensinner, S., Kucera-Hirzinger, V., Preiner, S., Reiter, K., Schuh, B., Weigelhofer, G. \& Zsuffa, I. 2006. Optimized management strategies for the biosphere reserve Lobau, Austria-based on a multi-criteria decision support system. Ecohydrology \& Hydrobiology, 6: 2536.

Hernández-Trejo, V., Avilés-Polanco, G., Ponce-Díaz, G. \& Lluch-Belda, D. 2017. Estimación de cuotas diferenciadas para permisos de pesca deportiva en Los Cabos, México. Un enfoque de costo de viaje. Economía Teoría y Práctica, 46: 139-171.
Hernández-Trejo, V.A., Germán, G.P.-D., Lluch-Belda, D. \& Beltrán-Morales, L.F. 2012. Economic benefits of sport fishing in e relative Los Cabos, Mexico: is the abundance a determinant? Journal of Sustainable Tourism, 161: 165-176.

Hicks, J.R. 1943. The four consumer's surpluses. Review of Economic Studies, 11(1): 31-41. doi: 10.2307/ 2967517

Hynes, S., Gaeven, R. \& O'Reilly, P. 2017. Estimating a total demand function for sea angling pursuits. Ecological Economics, 134: 73-81.

Hynes, S., O'Reilly, P. \& Corless, R. 2015. An on-site versus a household survey approach to modelling the demand for recreational angling: do welfare estimates differ? Ecosystem Services, 16: 136-145.

Klimley, A.P. \& Butler, S.B. 1988. Immigration and emigration of a pelagic fish assemblage to seamounts in the Gulf of California related to water mass movements using satellite imagery. Marine Ecology Progress Series, 49: 11-20.

Laplante, B., Meisner, C.M. \& Wang, H. 2006. Welfare measurement bias in household and on-site surveying of water-based recreation: an application to Lake Sevan, Armenia. World Bank Policy Research, Working Paper, 3932: 22 pp.

Lansdell, N. \& Gangadharan, L. 2003. Comparing travel cost models and the precision of their consumer surplus estimates: Albert Park and Maroondah Reservoir. Australian Economic Paper, 42: 399-417.

Levin, R.I. \& Rubin, D.S. 2010. Estadística para administración y economía. Pearson Educación, Madrid.

Mankiw, N.G. \& Taylor, M.P. 2017. Economía. Ediciones Paraninfo, Madrid.

McConnell, K.E. \& Strand, I. 1981. Measuring the cost of time in recreation demand analysis: an application to sportfishing. American Journal of Agricultural Economics, 63: 153-156. doi: 10.2307/1239822

McKean, J.R., Johnson, D.M. \& Taylor, R.G. 2001. The value of sport fishing in the Snake River Basin of Central Idaho. Western Agricultural Economics Association, 2001 Annual Meeting (July 8-11), Logan, Utha 36190, USA. Western Agricultural Economics Association, Wisconsin, $16 \mathrm{pp}$.

Mendes, I. \& Proença, I. 2011. Measuring the social recreation per-day net benefit of the wildlife amenities of a national park: a count-data travel-cost approach. Environmental Management, 48: 920. doi: 10.1007/ s00267-011-9733-1

Meza-Cuellar, N.A. 2017. Valoración socieconómica de la pesca deportiva y preferencia por capturar dorado (Coryphaena hippurus) en la zona de Los Barriles- 
Buenavista, Baja California Sur, por el método costo de viaje. Tesis de Maestría, Centro de Investigaciones Biológicas del Noroeste, La Paz, 72 pp.

Mitchell, R.C. \& Carson, R.T. 2013. Using surveys to value public goods: the contingent valuation method. RFF Press, Washington DC.

Oliveto-Andrade, A.J.G. 2018. Variabilidad e impacto socioeconómico de la pesca deportiva: localidades aledañas a Isla Cerralvo. Tesis de Licenciatura, Universidad Autónoma de Baja California Sur, BCS, $59 \mathrm{pp}$.

Ortega-García, S. 2010. Efecto de El Niño en los peces pelágicos mayores de importancia para la pesca deportiva en BCS México. FONMAR-Gobierno del Estado de BCS, BCS, 32 pp.

Ortega-García, S., Klett-Traulsen, A. \& Ponce-Díaz, G. 2003. Analysis of sportfishing catch rates of striped marlin (Tetrapturus audax) at Cabo San Lucas, Baja California Sur, Mexico, and their relation to sea surface temperature. Marine and Freshwater Research, 54: 483-488.

Pérez Valencia, S.A. 2004. Estudio de la pesca deportivorecreativa en la región de Los Cabos, BCS, con énfasis en el destino de las capturas. Tesis de Maestría, Centro de Investigaciones Biológicas del Noroeste, La Paz, 63 pp.

Ponce-Díaz, G., Ortega-García, S. \& Hernández-Vázquez, S. 2003. Lunar phase and catch success of the striped marlin (Tetrapturus audax) in sport fishing at Los Cabos, Baja California Sur, Mexico. Revista de Biología Tropical, 51(2): 555-560.

Prayaga, P., Rolfe, J. \& Stoeckl, N. 2010. The value of recreational fishing in the Great Barrier Reef, Australia: a pooled revealed preference and contingent behaviour model. Marine Policy, 34: 244-251.

Received: 28 May 2019; Accepted: 14 January 2020
Randall, A. 1994. A difficulty with the travel cost method. Land Economics, 70: 88-96.

Rivera-Castañeda, P. 2002. Valoración económica del servicio ambiental recreación en bahía de los Ángeles, Baja California. Tesis de Maestría, El Colegio de la Frontera, Tijuana, $130 \mathrm{pp}$.

Roehl, W.S., Ditton, R.B., Holland, S.M. \& Perdue, R.R. 1993. Developing new tourism products: sport fishing in the south-east United States. Tourism Management, 14: $279-288$.

Shrestha, R.K. \& Loomis, J.B. 2001. Testing a metaanalysis model for benefit transfer in international outdoor recreation. Ecological Economics, 39: 67-83.

Shrestha, R.K., Seidl, A.F. \& Moraes, A.S. 2002. Value of recreational fishing in the Brazilian Pantanal: a travel cost analysis using count data models. Ecological Economics, 42: 289-299. doi: 10.1016/S0921-8009 (02)00106-4

Sutton, S.G., Stoll, J.R. \& Ditton, R.B. 2001. Understanding anglers' willingness to pay increased fishing license fees. Human Dimensions of Wildlife, 6: 115130.

Von Borstel-Juárez, O.S., Beltrán-Morales, L.F., PonceDíaz, G., Almendarez-Hernández, L.C., Meza-Cuellar, N.A. \& Zepeda-Domínguez, J.A. 2019. Caracterización socioeconómica de la pesca deportiva en tres localidades de Baja California Sur, México. Sociedad y Ambiente, 21: 207-226.

Vuelta, A.C. \& de la Fuente, L.G. 2004. Métodos directos e indirectos en la valoración económica de bienes ambientales. Aplicación al valor de uso recreativo del Parque Natural de Somiedo. Estudios de Economía Aplicada, 22: 729-730. 